\title{
A Possible Role of Glutathione S-Transferase in Rat Ovary and Testis
}

\author{
Fumio FuKaI, ${ }^{*}$ Hiroyuki OHTAKI, Toshihiro UedA, \\ and Takashi KATAYAMA \\ Department of Patho-Physiology, Faculty of Pharmaceutical Sciences, \\ Science University of Tokyo, Tokyo 162, Japan
}

(Received December 2, 1991)

Summary Glutathione S-transferase (GST) isozymes purified from rat ovary and testis cytosols were grouped immunochemically into two classes, alpha and mu. The class-alpha isozymes of both tissue cytosols exhibited catalytic activities of $\Delta^{5}$-3-ketosteroid isomerase and glutathione (GSH)-peroxidase. The class-mu isozymes were characterized by showing potent GSH-conjugation activity toward a wide variety of electrophilic compounds. The most conspicuous difference in the isozymes between these gonadal tissue cytosols was shown to reside in the isozymes having $\Delta^{5}$-3-ketosteroid isomerase activity. Only GST 1-2 among the testicular GST isozymes showed the steroid isomerase activity, whereas two distinct ovarian class-alpha isozymes, GSTs 1-2 and 1'-1', revealed the activity. Immunohistochemical analysis showed that the class-alpha isozymes were localized in the cells related to steroid hormone production such as testicular interstitial Leydig cells and the ovarian cells of theca folliculi and interstices, and the corpus lutheum. The class-mu isozymes were shown to be distributed throughout both gonadal tissues, but in the testis a remarkable localization of the isozymes was observed within Sertoli cells. These results suggest that each class of GST isozymes may be distributed in appropriate locations of the gonadal tissues to serve roles in generation of steroid hormones or in protection of ovum and sperm from various xenobiotics.

Key Words: glutathione S-transferase, ovary, testis, detoxification, steroid isomerase

Glutathione S-transferase (GST EC 2.5.1.18) is a group of cytoplasmic enzymes that catalyze the conjugation of glutathione (GSH) with various electro-

* To whom correspondence should be addressed. 
philes [1-3]. A prominent feature of GST in an organism is the existence of many isozymes, each of which is composed of various pairs of subunits [2, 3]. GST isozymes can be grouped species-independently into three classes, classes alpha, $\mathrm{mu}$, and pi, based on their structural, immunochemical, and catalytic properties [4, $5]$. The enzymes are found most abundantly in liver cytosol, where they constitute nearly $10 \%$ of the soluble proteins [1]. GST isozymes of rat liver cytosol are comprised mainly of class-alpha isozymes (GSTs 1-1, 1-2, and 2-2) and class-mu ones (GSTs 3-3, 3-4, and 4-4) [6]. We reported recently that the isozymes of classes alpha and mu have the different functions in the hepatic detoxification system [7, 8]. Class-mu isozymes exhibit potent GSH-conjugation activities toward a wide variety of electrophilic compounds. In contrast, some of the class-alpha isozymes (GSTs 1-1 and 1-2) scavenge bilirubin to protect GSTs from its inhibitory action. On the other hand, it has recently been reported that qualitative and quantitative analyses of GST isozymes may provide indices of tissue damage including that of liver $[8,9]$ and hepatocarcinogenesis [10]. For example, GST-P was identified as a new reliable marker enzyme for preneoplastic lesions in rat hepatocarcinogenesis [10]. Hepatic GST isozymes were shown to be released from the cytosol into the bloodstream with a unique pattern of leakage that corresponded to the extent of liver damage [8]. Thus, knowledge about the GST system of mammalian tissues is important not only for basic understanding of GST functions in the detoxification system but also for investigation of the possible value of the GST measurement in clinical practice.

It has been well documented that GSTs exist widely also in extrahepatic tissues with distinct tissue specificities [11-15]. Particularly high GST-conjugation activity exists in testicular cytosol of rats and humans. Comparison of testicular isozymes with hepatic forms has been made by many investigators [16-19]. In spite of extensive knowledge about the biochemical properties of the testicular isozymes, their primary role in the tissue has remained obscure. Moreover, little is known concerning the enzymes in another gonadal tissue, the ovary, although only a limited number of isozymes including ligandin (GST 1-2) has been reported to be present in the ovarian cytosol [20-22]. For understanding of the significance of GSTs in gonadal tissues, it would be necessary to accumulate information also about the ovarian GSTs. We have purified the GST isozymes from rat ovary cytosol as well as from the testis cytosol and have analyzed their enzymatic properties. Immunohistochemical localization of the isozymes in these gonadal tissues has also been investigated. Results of the correlation between enzymatic function of the GST isozymes and their cellular localization in the gonadal tissues may provide an important basis for understanding of the possible role of the GST in the gonadal tissues.

\section{MATERIALS AND METHODS}

Materials. Sephadex G-75, PBE 118, PBE 94, Pharmalyte, Polybuffer 96, and 
Polybuffer 74 were purchased from Pharmacia LKB Biotechnology (Uppsala, Sweden). Leukotriene $\mathrm{A}_{4}\left(\mathrm{LTA}_{4}\right)$-methylester was obtained from Wako Pure Chemical Industries (Tokyo). S-Hexylglutathione Sepharose was prepared according to the method of Mannervik and Guthenberg [23]. $\Delta^{5}$-Androstene-3,17-dione and $\Delta^{5}$-pregnene-3,20-dione were prepared as reported previously [24] from $\Delta^{5}$-androstene-3-ol-17-one and $\Delta^{5}$-pregnene-3-ol-20-one, respectively.

Assay of GST activity. GSH-conjugation activity was measured at $30^{\circ} \mathrm{C}$ as described earlier [25], with 1-chloro-2,4-dinitrobenzene (CDNB), 1,2-dichloro-4nitrobenzene (DCNB), $p$-nitrobenzylchloride (NBC), trans-4-phenyl-3-butene-2one (PBO), or bromosulfophthalein (BSP) used as substrate. GSH-dependent peroxidase (GSH-peroxidase) activity was assayed with cumene hydroperoxide (CHP) or $\mathrm{H}_{2} \mathrm{O}_{2}$ [26]. GSH-peroxidase activity derived from GST was expressed as the apparent peroxidase activity, which was calculated by subtraction of the activity toward $\mathrm{H}_{2} \mathrm{O}_{2}$ from that toward CHP. $\Delta^{5}$-3-Ketosteroid isomerase activity was determined as reported by Benson and Talalay [27], by use of $\Delta^{5}$-androstene3,17-dione or $\Delta^{5}$-pregnene-3,20-dione as substrate. LTC $_{4}$ synthase activity was assayed at $37^{\circ} \mathrm{C}$ according to the method reported by Yoshimoto et al. [28], which utilizes $\mathrm{LTA}_{4}$-methylester as substrate.

Purification of GST cytosolic isozymes from rat ovary and testis. Wistar strain rats of both sexes and weighing 200-250 g were anesthetized with diethylether, and the ovaries or testes were collected. A part of the tissues was fixed immediately with formalin for histochemical studies, and the remaining (about 7 $\mathrm{g}$ of each tissue) was homogenized with 2 vols of $20 \mathrm{~mm}$ Tris- $\mathrm{HCl}$ buffer, $\mathrm{pH} 7.4$ ( $\mathrm{T}$ buffer), containing $0.25 \mathrm{M}$ sucrose to prepare the cytosol. Purification of GST isozymes from each cytosol was carried out in the same way as used for rat liver GST isozymes [9] as follows: Each cytosol was subjected to gel filtration on a Sephadex G-75 column $(2.6 \times 95 \mathrm{~cm})$ equilibrated with $\mathrm{T}$ buffer, and the GST fractions with a molecular weight $\left(M_{\mathrm{r}}\right)$ of around $50 \mathrm{kDa}$ were pooled. The pool was applied to affinity chromatography with a S-hexylglutathione Sepharose column $(2.6 \times 5 \mathrm{~cm})$. After washing of the column with $\mathrm{T}$ buffer containing $0.2 \mathrm{M}$ $\mathrm{NaCl}$, the GST was eluted with $5 \mathrm{~mm}$ S-hexylglutathione in the same buffer, dialyzed against $\mathrm{T}$ buffer, and then applied to a PBE 118 chromatofocusing column $(1 \times 50 \mathrm{~cm})$ equilibrated with $25 \mathrm{~mm}$ triethylamine- $\mathrm{HCl}$ buffer $(\mathrm{pH} \mathrm{11.0})$. Elution was performed with $700 \mathrm{ml}$ of Pharmalyte that had been diluted 80 -fold with water and adjusted to $\mathrm{pH} 7.0$ with $\mathrm{HCl}$. Isozymes with more acidic $\mathrm{p} I \mathrm{~s}$, which were still retained by the column, were eluted with $1 \mathrm{M} \mathrm{NaCl}$ and desalted by dialysis against $25 \mathrm{~mm}$ imidazole- $\mathrm{HCl}$ buffer $(\mathrm{pH} 7.5$ ). This preparation was then subjected to chromatofocusing on a PBE 94 column $(0.8 \times 25 \mathrm{~cm})$ equilibrated with the imidazole buffer. Elution was performed with $200 \mathrm{ml}$ of Polybuffer 74- $\mathrm{HCl}(\mathrm{pH} 5.0)$ diluted 15-fold with water. Each GST isozyme thus separated was subjected once again to the affinity chromatography with a small column $(0.7 \times 2$ $\mathrm{cm}$ ) of S-hexylglutathione Sepharose to concentrate and remove the Pharmalyte and Polybuffer from the purified preparations.

Vol. 12, No. 2, 1992 
Immunoblot analysis. Immunoblot analysis was carried out to define the immunochemical properties of GST isozymes purified from rat ovarian and testicular cytosols. For this purpose, we employed antibodies raised against rat liver GST 1-2 and GST 3-4 [8, 29]. As characterized previously, anti-GST 1-2 antibody recognizes immunochemically the isozymes belonging to class-alpha (GSTs 1-1, 1-2, and 2-2), but not the class-mu ones (GSTs 3-3, 3-4, and 4-4). On the other hand, anti-GST 3-4 antibody reacts with the class mu, but not with the class alpha. In this paper, anti-GST 1-2 and anti-GST 3-4 antibodies are referred to as anti-class-alpha and anti-class-mu antibodies, respectively. After SDSpolyacrylamide slab gel electrophoresis, proteins in the gel were electrophoretically transferred to a nitrocellulose membrane (Bio-Rad, Richmond). Nonspecific binding sites on the membrane were blocked by incubation $\left(37^{\circ} \mathrm{C}, 1 \mathrm{~h}\right)$ with the blocking buffer, 5\% skim milk (Difco Laboratories, Detroit) in phosphate-buffered saline (PBS). Following the blocking, the membrane was incubated $\left(37^{\circ} \mathrm{C}, 1 \mathrm{~h}\right)$ with each antibody (about $10 \mu \mathrm{g}$ IgG in $1 \mathrm{ml}$ of the blocking buffer). After washing, immunoreactive substances were detected with a Bio-Rad goat anti(rabbit IgG) antibody-horseradish peroxidase immunoblot assay kit.

Localization of GST in rat ovary and testis. Following the fixation of the tissue, the tissue blocks were dehydrated and embedded in paraffin. Deparaffinated sections $4 \mu \mathrm{m}$ in thickness were used for immunohistochemical localization of GST by the peroxidase-antiperoxidase (PAP) technique using the anti-class-alpha or anti-class-mu antibody, as described previously [8]. In the control experiments, sections were exposed to normal rabbit serum.

\section{RESULTS}

\section{Purification and characterization of GST isozymes of rat ovarian and testicular cytosol}

The cytosol fraction of rat ovary was found to have a substantial amount of GSH-conjugation activity as measured with a strong electrophilic substrate, CDNB, but its tissue content $(10.7 \mu \mathrm{mol} / \mathrm{min} / \mathrm{g}$ ovary) was about 4 times lower than that of the testicular cytosol $(42 \mu \mathrm{mol} / \mathrm{min} / \mathrm{g}$ testis $)$. The conjugation activity toward other substrates such as DCNB, NBC, and BSP also showed 3-4 times lower values than those obtained for the testicular cytosol (data not shown). In contrast, both gonadal tissue cytosols showed a similar level of the activity to promote the enzymatic conversion of $\Delta^{5}$-androstene-3,17-dione to $\Delta^{4}$-androstene3,17-dione ( $\Delta^{5}$-3-ketosteroid isomerase activity), i.e., $23 \mathrm{nmol} / \mathrm{min} / \mathrm{g}$ ovary vs. 30 $\mathrm{nmol} / \mathrm{min} / \mathrm{g}$ testis. Since the $\Delta^{5}$-3-ketosteroid isomerase activity detected in both of the cytosols was shown to depend on the reduced form of GSH but not to require NAD, the activity would be ascribable to GST and not to microsomal steroid isomerase (EC 5.3.3.1). To define constituents of the gonadal GST systems, purification of individual GST isozymes was carried out.

The GST activity was separated from the bulk proteins of rat ovarian cytosol 
by a combination of gel filtration and S-hexylglutathione Sepharose affinity chromatography, and various isozymes were subsequently resolved by chromatofocusing. As shown in Fig. 1, five isozymes having basic $\mathrm{p} I \mathrm{~s}$ and four acidic isozymes were obtained, in which the basic isozymes comprised nearly $70 \%$ of the total GSH-conjugation activity. The major constituents of ovarian isozymes (peaks I-V and VIII) were shown to arise from binary combinations of subunits with $M_{\mathrm{r}}$ of $25,26.5$, and $28 \mathrm{kDa}$ (Fig. 2A). The $25-$ and $28-\mathrm{kDa}$ subunits in peaks I, II, and IV showed immunochemical cross-reactivity with anti-class-alpha antibody, but not with anti-class-mu antibody (Fig. 2 B and C). On the contrary, all the $26.5-\mathrm{kDa}$ subunits of peaks III, V, and VIII reacted with anti-class-mu antibody, but not with anti-class-alpha antibody (Fig. 2 B and C). The results indicate that the isozymes of peaks I, II, and IV belong to class alpha, and those of peaks III, V, and VIII, to class mu. Heterogeneity in the protein-stains between the 25and $28-\mathrm{kDa}$ bands of the peak I seemed to be due to a contamination from peak II material. Similarly, the immuno-blot at a $M_{\mathrm{r}}$ of $25 \mathrm{kDa}$ observed with the peak II would also be from the peak I.

In order to discriminate more clearly between the different types of subunits, various substrates were used to measure enzymatic activity. A summary of the substrate specificities of each purified isozyme is given in Table 1. The isozymes

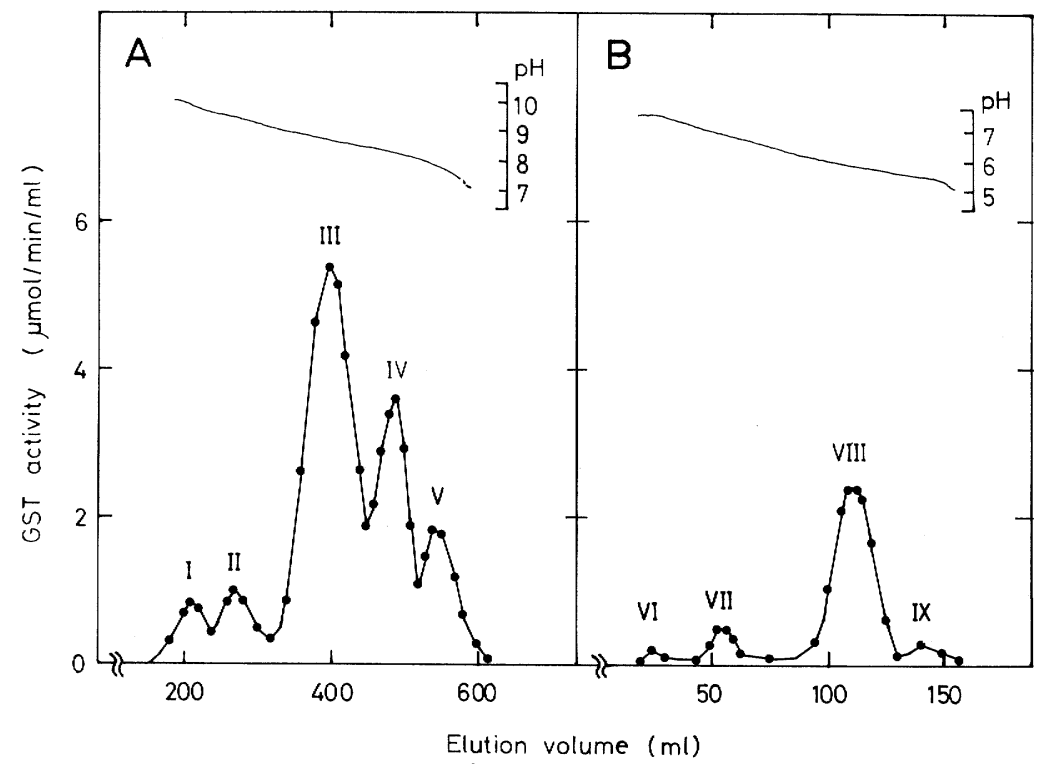

Fig. 1. Separation of cytosolic GST isozymes of rat ovary by chromatofocusing. (A) GST partially purified by a combination of gel filtration and S-hexyl GSH Sepharose affinity chromatography was subjected to chromatofocusing at $\mathrm{pH}$ 10.5-7.0. (B) Acidic GST isozymes, which were retained on the above column and eluted with $1 \mathrm{M} \mathrm{NaCl}$, were separated by chromatofocusing at $\mathrm{pH}$ 7.5-5.0. GSH-conjugation activity was assessed with CDNB. 
belonging to class mu (peaks III, V, and VIII) showed relatively high GSHconjugation activities toward not only CDNB but also toward other substrates such as DCNB, NBC, BSP, and PBO. Furthermore, these isozymes also revealed

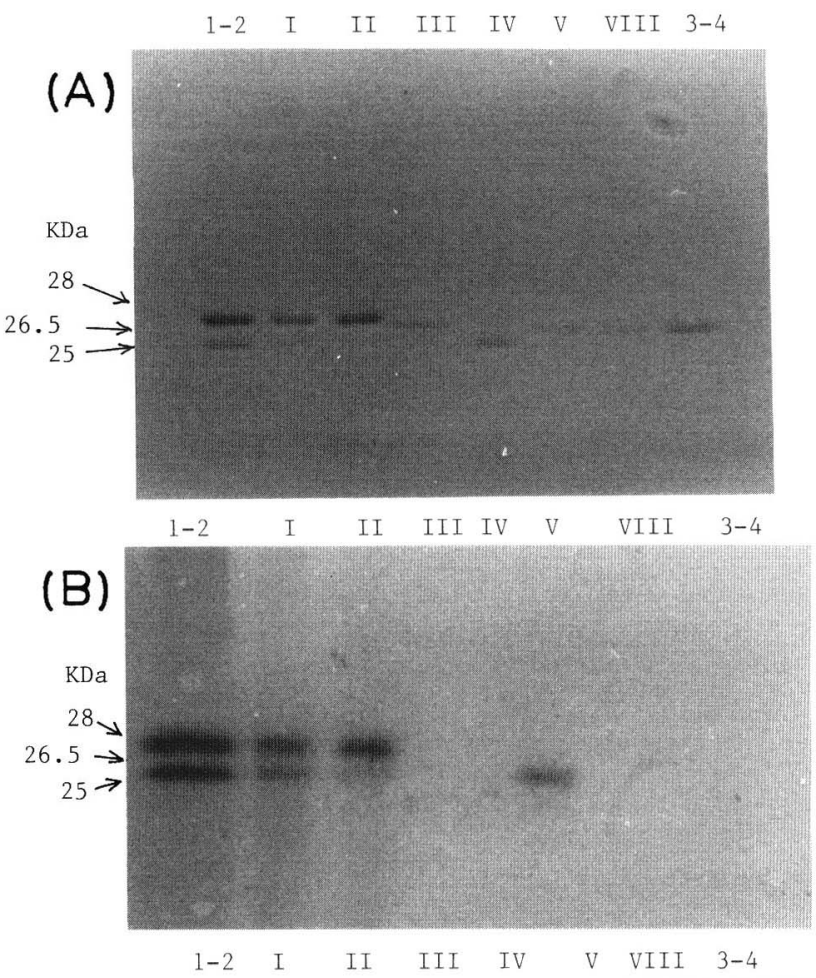

(C)

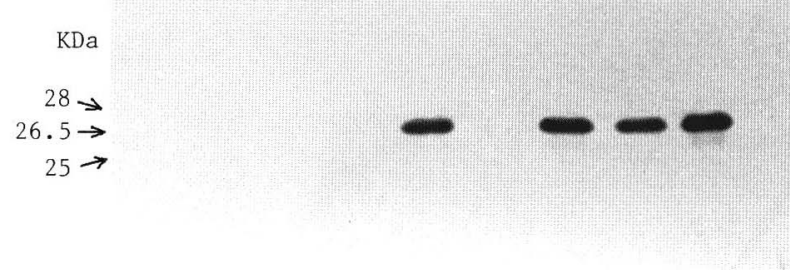

Fig. 2. Analysis of subunit composition and immunochemical properties of the GST isozymes purified from rat ovarian cytosol. Purified proteins $(10 \mu \mathrm{g}$ each) were subjected to SDS-polyacrylamide gel electrophoresis on $12.5 \%$ polyacrylamide gels. After the electrophoresis, proteins were stained with Coomassie brilliant blue R-250 (A), and the proteins in other gels were transferred electrophoretically to nitrocellulose membranes for the immunoblot analysis (B and C). Anti-class-alpha antibody (B) or anti-class-mu antibody (C) was used as a primary antibody. Lanes from left to right: rat liver GST 1-2, peaks I-V and VIII in Fig. 1, and rat liver GST 3-4. 
the conjugation activity toward an epoxide residue of $\mathrm{LTA}_{4}$-methylester to form $\mathrm{LTC}_{4}$-methylester. Thus, the ovarian class-mu isozymes were characterized by exhibiting potent GSH-conjugation activities toward a wide variety of electro-

Table 1. Substrate specificities of GST isozymes purified from rat ovarian cytosol.

\begin{tabular}{|c|c|c|c|c|c|c|}
\hline \multirow{2}{*}{ Substrate } & \multicolumn{6}{|c|}{ GST activity $(\mu \mathrm{mol} / \mathrm{min} / \mathrm{mg}$ protein $)$} \\
\hline & Peaks I & II & III & IV & $\mathrm{V}$ & VIII \\
\hline $\begin{array}{l}\text { 1-Chloro-2,4- } \\
\text { dinitrobenzene }\end{array}$ & $12.5 \pm 2.5$ & $14.3 \pm 3.6$ & $29.5 \pm 3.6$ & $17.2 \pm 2.9$ & $16.8 \pm 3.0$ & $65.6 \pm 10.0$ \\
\hline $\begin{array}{l}\text { 1,2-Dichloro-4- } \\
\text { nitrobenzene }\end{array}$ & $\mathrm{ND}^{\mathrm{a}}$ & ND & $2.92 \pm 0.83$ & $0.26 \pm 0.07$ & $1.56 \pm 0.54$ & $0.41 \pm 0.10$ \\
\hline$p$-Nitrobenzylchloride & ND & ND & $6.15 \pm 1.23$ & $0.53 \pm 0.12$ & $4.60 \pm 0.81$ & $0.87 \pm 0.13$ \\
\hline Bromosulfophthalein & ND & ND & $0.53 \pm 0.10$ & ND & $0.23 \pm 0.03$ & $0.11 \pm 0.04$ \\
\hline $\begin{array}{l}\text { Trans-4-phenyl-3- } \\
\text { butene-2-one }\end{array}$ & ND & ND & $0.06 \pm 0.02$ & ND & $1.11 \pm 0.35$ & ND \\
\hline Cumen hydroperoxide & $4.13 \pm 0.10$ & $9.96 \pm 1.34$ & $0.31 \pm 0.07$ & $0.33 \pm 0.08$ & ND & $0.22 \pm 0.06$ \\
\hline $\begin{array}{l}\Delta^{5} \text {-Androstene-3,17- } \\
\text { dione }\end{array}$ & $1.98 \pm 0.54$ & $0.25 \pm 0.09$ & $0.04 \pm 0.02$ & $1.20 \pm 0.58$ & $0.03 \pm 0.01$ & ND \\
\hline $\begin{array}{l}\Delta^{5} \text {-Pregnene-3,20- } \\
\text { dione }\end{array}$ & $3.76 \pm 0.96$ & $0.54 \pm 0.16$ & $0.03 \pm 0.01$ & $2.25 \pm 0.67$ & $0.05 \pm 0.02$ & ND \\
\hline LTA $_{4}$-methylester ${ }^{\mathrm{b}}$ & ND & $5.2 \pm 0.67$ & $18.7 \pm 2.06$ & $4.6 \pm 0.77$ & $107.5 \pm 22.80$ & $218.4 \pm 39.15$ \\
\hline
\end{tabular}

${ }^{\mathrm{a}} \mathrm{ND}$, not detected. ${ }^{\mathrm{b}} \mathrm{nmol} / 5 \mathrm{~min} / \mathrm{mg}$ protein. All values given are means $\pm \mathrm{SD}$ from triplicate experiments.

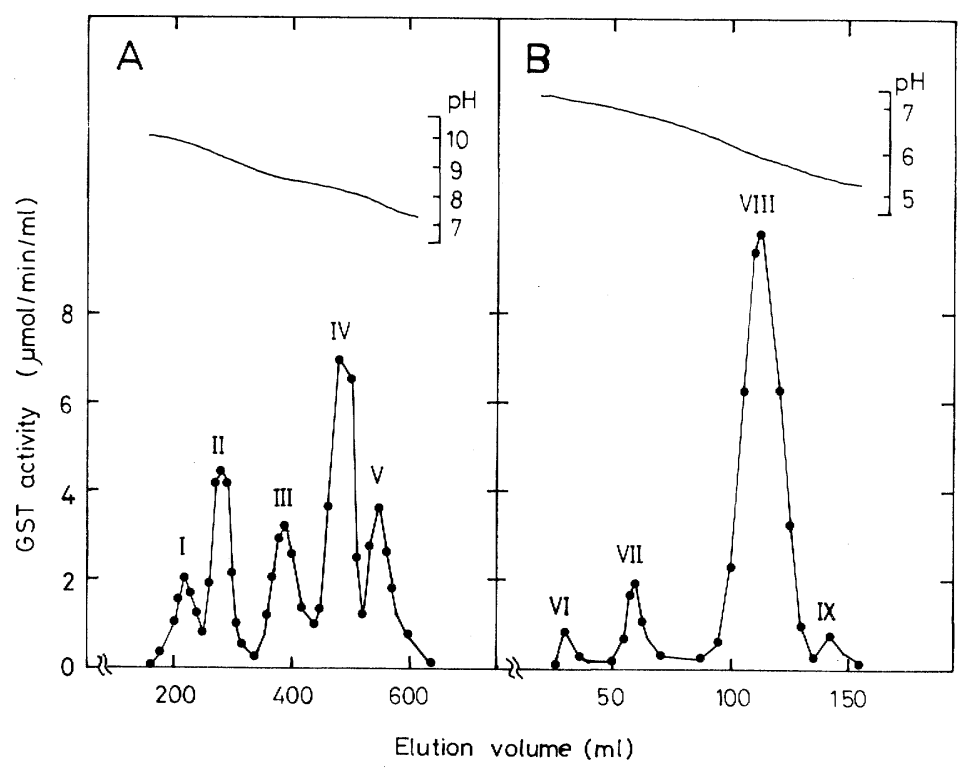

Fig. 3. Separation of rat testicular GST isozymes by chromatofocusing. (A) Partially purified GST isozymes were subjected to chromatofocusing at $\mathrm{pH}$ 10.5-7.0. (B) Acidic GST isozymes eluted with $1 \mathrm{M} \mathrm{NaCl}$ from the above column were separated by chromatofocusing at $\mathrm{pH} 7.5-5.0$. GSH-conjugation activity was measured with CDNB.

Vol. 12, No. 2, 1992 
philes including aryl, allyl, and epoxide compounds. The isozyme of peak VIII showed the highest specific activities toward CDNB and LTA 4 -methylester (Table 1). Based on the value of specific activities for each isozyme, taken together with the subunit structures and their $\mathrm{p} I$ values, the ovarian class-mu isozymes, peaks III, V, and VIII, were assumed to be GSTs 3-3, 4-4, and 6-9, respectively. On the other hand, the isozymes of class alpha were clearly distinguished from the class-mu ones by their high $\Delta^{5}$-3-ketosteroid isomerase and GSH-peroxidase activities. The
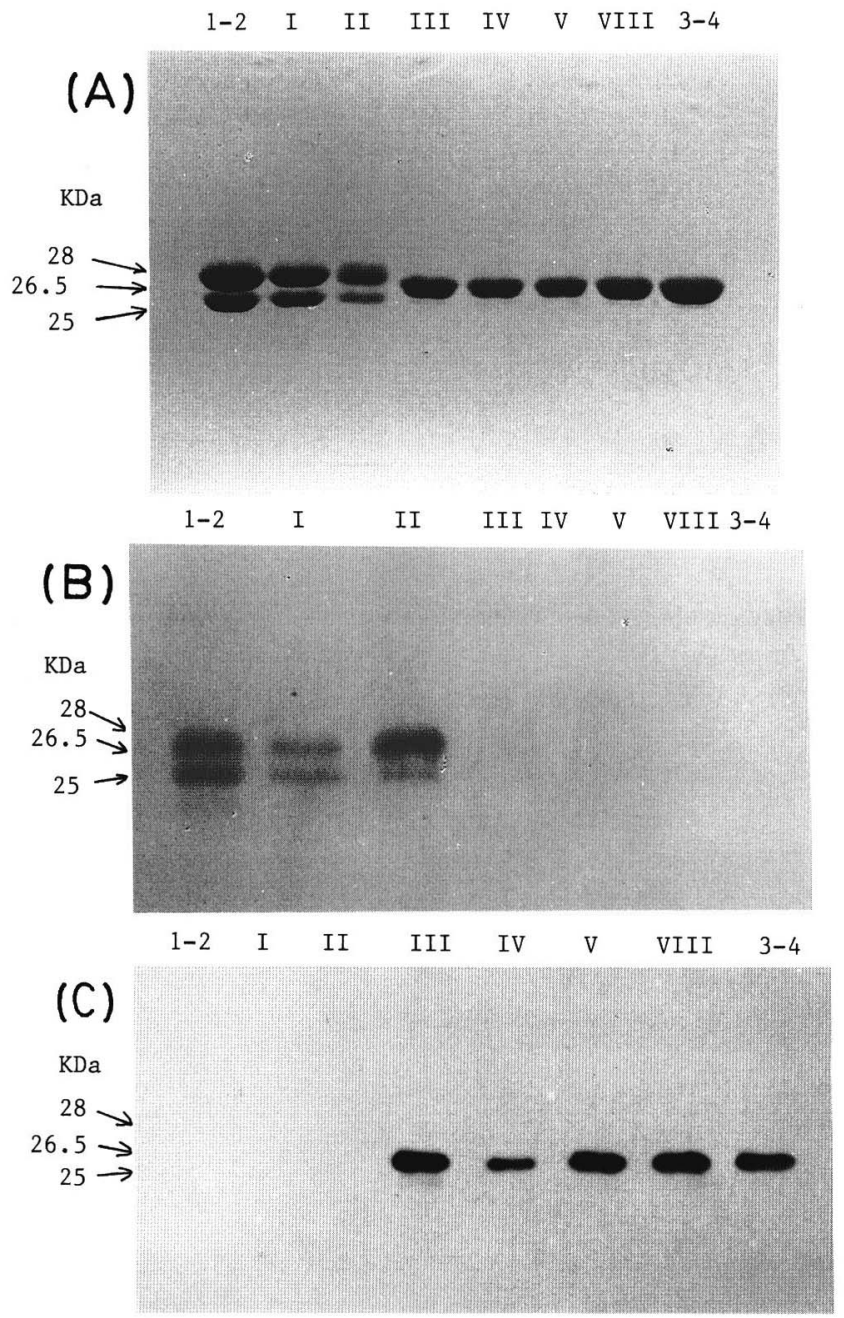

Fig. 4. Analyses of the subunit compositions of the GST isozymes purified from testicular cytosol and their immunochemical properties. (A) SDS-polyacrylamide gel electrophoresis with $12.5 \%$ gel. (B) Immunoblot analysis. About $25 \mu \mathrm{g}$ of each protein was subjected to the electrophoresis. Lanes from left to right: rat liver GST 1-2, peaks I-V and VIII in Fig. 3, and rat liver GST 3-4. 
$\Delta^{5}$-3-ketosteroid isomerase activity was most remarkable in peak I, and peak II contained the highest GSH-peroxidase activity (Table 1). Since it has been well defined that the steroid isomerase activity is derived from subunit 1 and that the GSH-peroxidase activity is highest in subunit 2, peaks I and II were deduced to be GSTs 1-2 and 2-2, respectively. The steroid isomerase activity was detected not only in peak I but also in peak IV. This isozyme with $\mathrm{p} I 8.2$ was also composed of a class-alpha subunit with a $M_{\mathrm{r}}$ of 25,000 . These observations indicate that the $25-\mathrm{kDa}$ subunit in this peak is very similar to subunit 1 , whereas the $\mathrm{p} I$ value of the peak IV isozyme was too low to conclude that the isozyme is identical with GST 1-1 (pI 9.5-10). The 25-kDa subunit in peak IV may be an isotype (GST $\left.1^{\prime}-1^{\prime}\right)$ of subunit 1 that has been isolated from rat liver and lung.

The steroid isomerase activity detected in peak I was somewhat higher than that in peak IV as expressed by the specific activity. However, from an estimation of the amount of protein recovered in these peaks, nearly $70 \%$ of the total isomerase activity detected in the cytosol was accounted for by the isozyme of peak IV. $\Delta^{5}$-Pregnene-3,20-dione was much more active compared with $\Delta^{5}$-androstene3,17-dione as a substrate for either isozyme (Table 1). Thus, two distinct GST isozymes were isolated as "steroid isomerase" from the ovarian cytosol.

GST isozymes in rat testicular cytosol have already been characterized by many investigators. It has been demonstrated that a major part of the GST activity of this cytosol is composed of the acidic isozyme termed GST 6-9. In agreement with previous studies, about $50 \%$ of GSH-conjugation activity toward CDNB resided in the peak VIII isozyme with pI 5.9 (Fig. 3). The dominating acidic isozyme was classified immunochemically to be class mu (Fig. 4). This isozyme exhibited the highest specific activities toward CDNB and LTA $_{4}$-methylester

Table 2. Substrate specificities of GST isozymes purified from rat testicular cytosol.

\begin{tabular}{|c|c|c|c|c|c|c|}
\hline \multirow{2}{*}{ Substrate } & \multicolumn{6}{|c|}{ GST activity $(\mu \mathrm{mol} / \mathrm{min} / \mathrm{mg}$ protein $)$} \\
\hline & Peaks I & II & III & IV & $\mathrm{V}$ & VIII \\
\hline $\begin{array}{l}\text { 1-Chloro-2,4- } \\
\text { dinitrobenzene }\end{array}$ & $20.2 \pm 2.0$ & $20.4 \pm 1.8$ & $29.9 \pm 3.6$ & $16.5 \pm 1.8$ & $22.8 \pm 3.6$ & $58.4 \pm 4.1$ \\
\hline $\begin{array}{l}\text { 1,2-Dichloro-4- } \\
\text { nitrobenzene }\end{array}$ & $\mathrm{ND}^{\mathrm{a}}$ & ND & $2.75 \pm 0.32$ & $2.01 \pm 0.20$ & $3.56 \pm 0.42$ & $0.32 \pm 0.05$ \\
\hline$p$-Nitrobenzylchloride & ND & ND & $8.66 \pm 1.65$ & $10.04 \pm 2.01$ & $10.62 \pm 1.67$ & $2.00 \pm 0.40$ \\
\hline Bromosulfophthalein & ND & ND & $0.66 \pm 0.11$ & $0.20 \pm 0.04$ & $0.25 \pm 0.04$ & $0.14 \pm 0.03$ \\
\hline $\begin{array}{l}\text { Trans-4-phenyl-3- } \\
\text { butene-2-one }\end{array}$ & ND & ND & $0.11 \pm 0.04$ & $0.45 \pm 0.12$ & $1.83 \pm 0.36$ & ND \\
\hline Cumen hydroperoxide & $2.10 \pm 0.33$ & $5.63 \pm 0.70$ & ND & ND & ND & $0.34 \pm 0.08$ \\
\hline $\begin{array}{l}\Delta^{5} \text {-Androstene- } 3,17- \\
\text { dione }\end{array}$ & $3.67 \pm 0.52$ & $0.61 \pm 0.10$ & ND & ND & ND & ND \\
\hline $\begin{array}{l}\Delta^{5} \text {-Pregnene-3,20- } \\
\text { dione }\end{array}$ & $6.89 \pm 1.04$ & $1.12 \pm 0.30$ & ND & ND & ND & ND \\
\hline $\mathrm{LTA}_{4}$-methylester ${ }^{\mathrm{b}}$ & ND & ND & $20.6 \pm 3.67$ & $52.5 \pm 6.79$ & $99.2 \pm 14.42$ & $286.1 \pm 21.97$ \\
\hline
\end{tabular}

Vol. 12, No. 2, 1992 
(Table 2), being very similar to the major acidic isozyme of the ovary. The results indicate that this isozyme is identical with GST 6-9. On the other hand, basic GST isozymes of the testicular cytosol could also be grouped immunochemically into classes alpha (peaks I and II) and mu (peaks III-V), as seen from Fig. 4. Similar to the ovarian system, these classes were distinguishable by their catalytic properties (Table 2). The class-mu isozymes (peaks III-V) including the peak VIII

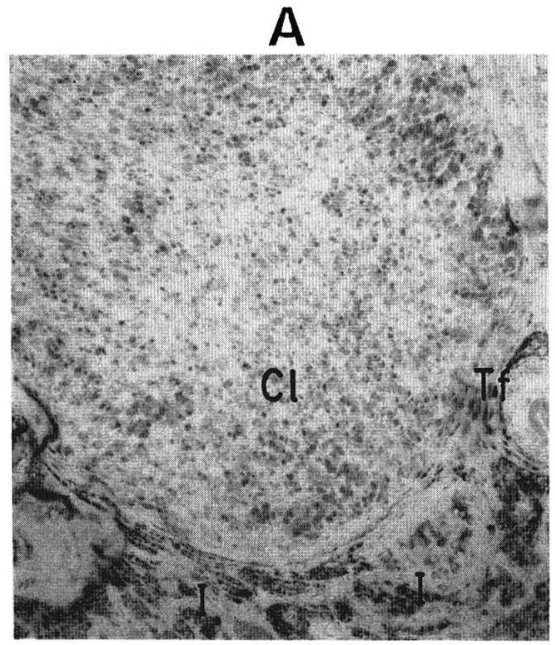

C

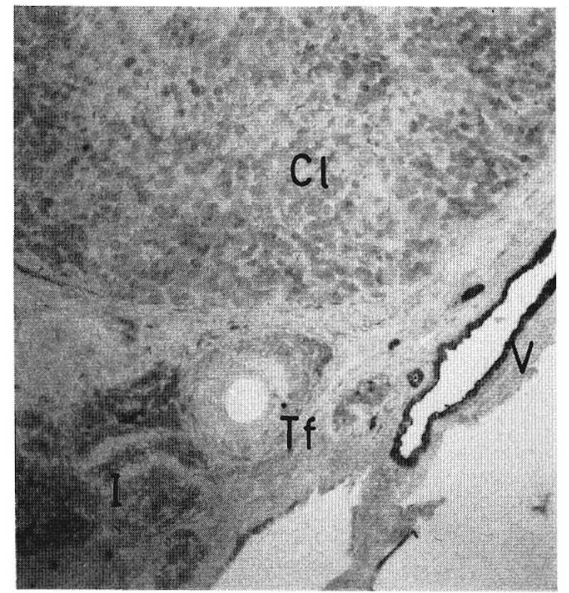

B

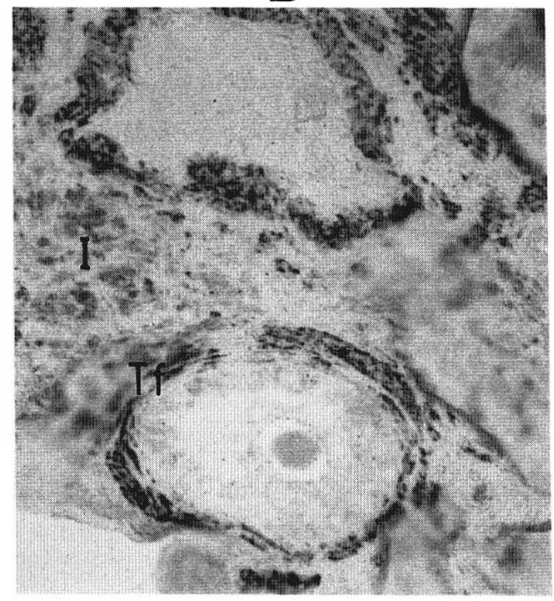

D

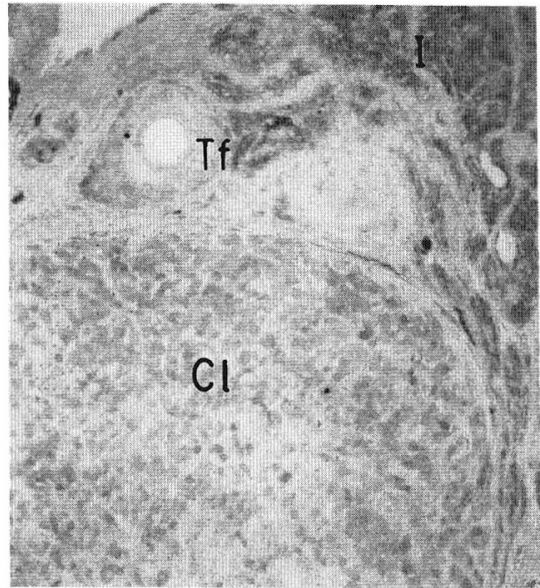

Fig. 5. Immunohistochemical localization of the GST isozymes in rat ovary. About $10 \mu \mathrm{g}$ $\mathrm{IgG} / \mathrm{ml}$ solution of anti-class-alpha ( $\mathrm{A}$ and $\mathrm{B}$ ) or anti-class-mu ( $\mathrm{C}$ and $\mathrm{D}$ ) antibody was used for the primary antibody. Photomicrographs were taken at 200- (A, C, and D) or 400- (B) magnification. Tf, theca folliculi; Cl, corpus luteum; I, interstitial area; V, blood vessel. 
isozyme had relatively high GSH-conjugation activities toward DCNB, NBC, BSP, and PBO. The class-alpha isozymes (peaks I and II) showed hardly any conjugation activity toward these substrates, but exhibited high activities of GSHperoxidase and $\Delta^{5}$-3-ketosteroid isomerase. These results demonstrate that the isozymes in peaks I-V are identical with GSTs 1-2, 2-2, 3-3, 3-4, and 4-4, respectively. In contrast to the ovarian GST system, only testicular GST 1-2 isozymes showed the $\Delta^{5}$-3-ketosteroid isomerase activity. However, enzymatic characteristics of the class-alpha and -mu isozymes were essentially in common with both gonadal GSTs.

\section{Immunohistochemical localization of GST isozymes in rat ovary and testis}

Localization of the two classes of the gonadal GST isozymes were analyzed. Immunohistochemical staining with anti-class-alpha antibody was observed in the cells of theca folliculi and in corpus luteum of the ovary (Fig. 5A and B). The ovarian interstices were also stained in dappled fashion with this antibody. On the other hand, existence of the class-mu isozymes in the corpus luteum and in the interstitial cells was also demonstrated by staining with the anti-class-mu antibody, whereas the staining in cells of the theca folliculi was not significant as compared with that seen with the anti-class-alpha antibody (Fig. 5C and D). Additionally, intense staining was observed in endothelial cells of blood vessels of

A

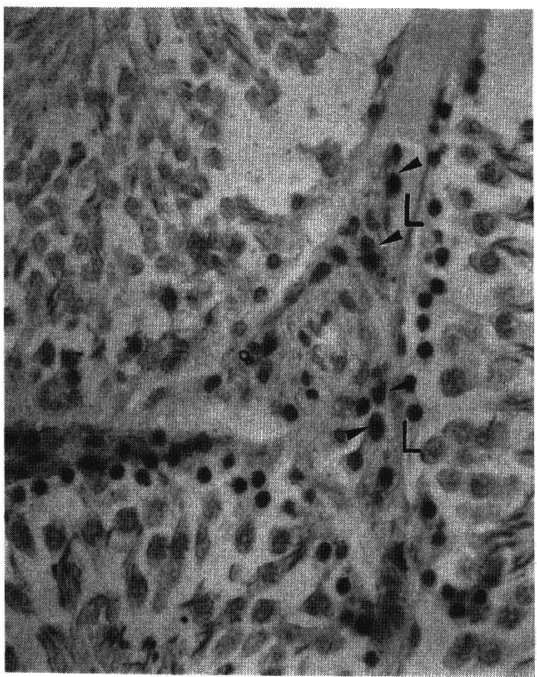

B

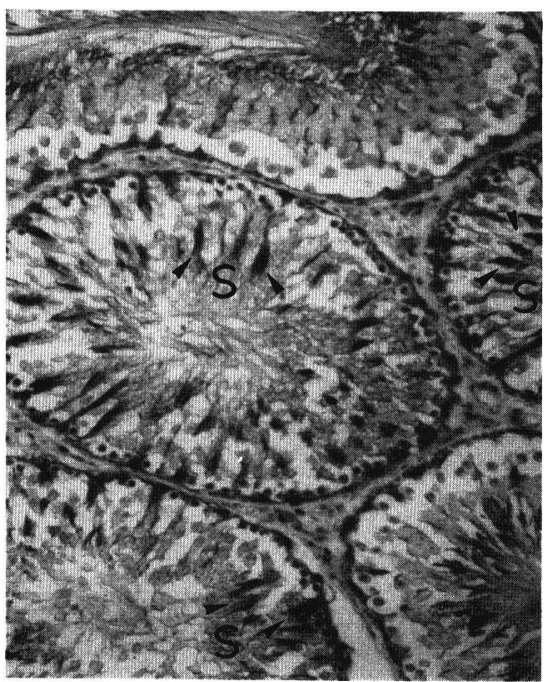

Fig. 6. Immunohistochemical localization of the GST isozymes in rat testis. Antı-classalpha (A) and anti-class-mu (B) antibodies. IgG concentration of each antibody was the same as in Fig. 5. Photomicrographs were taken at 200-magnification. Arrowheads indicate Leydig cells (L) and Sertoli cells (S). 
the ovary (Fig. 5C and D). In the testis, some interstitial Leydig cells, but not the cells in seminiferous tubules, were stained clearly with anti-class-alpha antibody (Fig. 6A). On the contrary, the staining with anti-class-mu antibody was evident at the cells within the seminiferous tubules (Fig. 6B). These positive cells occupied the interstices among the spermatogenic cells, and some of them were observed to bear bunches of maturing sperm. Therefore, these positive cells were taken to be Sertoli cells. Staining with this antibody was also detected in the interstitial cells, but more weakly. Thus, the two types of gonadal GST isozymes exhibited significant differences in their specific localizations.

\section{DISCUSSION}

Similar to rat hepatic GST isozymes, major constituents of rat gonadal GST isozymes could be grouped either immunochemically or functionally into two classes, classes alpha and mu. The class-mu isozymes were characterized by their potent GSH-conjugation activities toward a wide variety of electrophilic compounds. Also in the gonadal tissues these isozymes would contribute greatly to the excretion of foreign compounds by catalyzing the first step in mercapturic acid formation. On the other hand, the class-alpha isozymes hardly showed any GSH-conjugation activity toward such a wide spectrum of compounds, whereas they possessed the activities of $\Delta^{5}$-3-ketosteroid isomerase and GSH-peroxidase. Thus, characteristics of the enzymatic functions of these two classes were essentially commonly shared by both gonadal GST systems, but some significant differences were detected. The most conspicuous difference between the ovarian and testicular GSTs was found to reside in the isozymes having the $\Delta^{5}-3$ ketosteroid isomerase activity. In the testicular system only GST 1-2 isozymes showed the steroid isomerase activity, whereas in the ovary not only GST 1-2 but an additional class-alpha isozyme with $\mathrm{p} I 8.2$ (peak IV) was isolated as a "steroid isomerase" from the ovarian cytosol. This ovarian isozyme was assumed to be GST $1^{\prime}-1^{\prime}$ which is known as an isotype of GST 1-1 [30,31]. The high relative ratio of the steroid isomerase activity to the GSH-conjugation activity in the ovary would be explained by the presence of this isozyme as a "steroid isomerase."

For an understanding of the physiological role(s) of the gonadal GSTs, it is important to note the relationship between catalytic properties of GST isozymes and localization of these enzymes in the gonadal tissues. The ovarian class-alpha isozymes were distributed in regions related to steroid hormone synthesis, i.e., in the corpus luteum, theca folliculi, and the interstitial cells. Similarly, the testicular class-alpha isozymes were restricted to the interstitial Leydig cells, which are known to be responsible for androgen production. The result is essentially in agreement with the observation on human testis reported by Campbell et al. [21]. Utilizing a radioimmunoassay for the ligandin, Eidne et al. [22] recently reported a positive correlation between the ligandin (GST 1-2) content in rat testis or ovary and the circulating levels of the steroid hormone (testosterone or progesterone) at 
different stages of development. The class-alpha isozymes of GST may thus be associated with the steroid hormone production in these gonadal tissues. However, the isomerization reaction is considered to be catalyzed by the microsomal enzyme, because the steroid isomerase activity is rather dominant in membrane-bound fractions of steroidogenic tissues such as testis, ovary, and adrenal [32]. And microsomal isomerases (EC 5.3.3.1) distinct from GST have been purified [33-35]. Nevertheless, one can not neglect the fact that considerable levels of the isomerase activity are also detected in the cytosolic fraction of these tissues. The microsomal steroid isomerases require NAD or NADH as an allosteric effector [36], whereas the cytosolic "steroid isomerase" isolated here was demonstrated to depend on the reduced form of GSH, but not to require the nucleotides. Although the question of whether the cytosolic "steroid isomerases" actually participates in an integral manner in the steroid hormone production remains unanswered, it might be presumed that these two types of steroid isomerases, the microsomal and cytoplasmic, express their inherent activities under the directions of different endogenous factors such as the nucleotides and GSH. In addition, since the GST isozymes having the steroid isomerase activity possess the ability to bind hydrophobic compounds including bilirubin, carcinogens, and steroid hormone metabolites [7, 37 , the isozymes may also serve in the capacity of carrier protein for the hormones.

On the other hand, the class-mu isozymes characterized by their potent GSH-conjugation activities toward a wide variety of electrophiles were distributed over a wider area of both gonadal tissues as compared with the class-alpha isozymes. In the testis, the isozymes existed throughout the tissue, but a remarkable localization was observed within the seminiferous tubules, with particularly a high density in Sertoli cells. The Sertoli cells provide nutritional support and protection for developing germ cells. This location would be useful for protecting the germ cells from xenobiotics. Also in the ovary, the class-mu isozymes were distributed diffusely throughout the tissue. Significance of the ovarian isozymes in endothelial cells of blood vessels is still unclear, but this suggests that detoxification occurs actively in these regions. In any case, existence of this class of isozymes throughout both gonadal tissues would physiologically be important in protecting these cellular environments. From our results, we may speculate that rat gonadal GST isozymes are distributed in appropriate locations where they play important roles in generation and transport of steroid hormones or in protection of germ cells from various xenobiotics. Further studies are necessary to understand more precisely the function of individual GST isozymes in the gonadal tissues.

\section{REFERENCES}

1. Arias, I.M., Flischner, G., Kirsch, R., Mishkin, S., and Gatmaitan, Z. (1976): On the structure, regulation, and function of ligandin, in Glutathione: Metabolism and Function, ed. by Arias I.M. and Jakoby, W.B., Raven Press, New York, pp. 165-188.

Vol. 12, No. 2, 1992 
2. Jakoby, W.B. (1978): The glutathione S-transferase: A group of multi-functional detoxification proteins. Adv. Enzymol., 46, 383-414.

3. Mannervik, B. (1985): The isozymes of glutathione transferase. Adv. Enzymol., 57, 357-417.

4. Jakoby, W.B., Ketterer, B., and Mannervik, B. (1984): Glutathione transferases: Nomenclature. Biochem. Pharmacol., 33, 2539-2540.

5. Mannervik, B., Alin, P., Guthenberg, C., Jensson, H., Tahir, M.K., Warholm, M., and Jornvall, H. (1985): Identification of three classes of cytosolic glutathione transferase common to several mammalian species: Correlation between structural data and enzymatic properties. Proc. Natl. Acad. Sci. U.S.A., 82, 7202-7206.

6. Mannervik, B., and Jensson, H. (1982): Binary combination of four protein subunits with different catalytic specificities explain the relationship between six basic glutathione Stransferases in rat liver cytosol. J. Biol. Chem., 257, 9909-9912.

7. Fukai, F., Yatomi, S., Morita, T., Nishizawa, S., Nagai, T., and Katayama, T. (1989): Protection of glutathione S-transferase from bilirubin inhibition. J. Biochem., 105, 968-973.

8. Fukai, F., Nishizawa, S., Kurano, M., Taniguchi, K., and Katayama, T. (1989): Carbon tetrachloride-induced alteration of glutathione S-transferase in rat liver cytosol and plasma. J. Clin. Biochem. Nutr., 6, 175-185.

9. Beckett, G.J., and Hayes, J.D. (1987): Plasma glutathione S-transferase measurements and liver disease in man. J. Clin. Biochem. Nutr., 2, 1-24.

10. Sato, K. (1988): Glutathione S-transferases and hepatocarcinogenesis. Jpn. J. Cancer Res. (Gann), 79, 556-572.

11. Saneto, R.P., Awasthi, Y.C., and Srivastava, S.K. (1982): Glutathione S-transferases of bovine retina. Biochem. J., 205, 213-217.

12. Dao, D.D., Partridge, C., Kurosky, A., and Awasthi, Y.C. (1984): Human glutathione S-transferases. Characterization of the anionic forms from lung and placenta. Biochem. J., 221, 33-41.

13. Tu, C-P. D., Chang, M., and Reddy, D. (1984): The major rat heart glutathione Stransferases are anionic isozymes composed of $\mathrm{Yb}$ size subunits. Biochem. Biophys. Res. Commun., 123, 981-988.

14. Hayes, J.D., and Mantle, T.J. (1986): Use of immuno-blot techniques to discriminate between the glutathione S-transferase Yf, Yk, $\mathrm{Ya}, \mathrm{Yn} / \mathrm{Yb}$ and $\mathrm{Yc}$ subunits and to study their distribution in extrahepatic tissues. Biochem. J., 233, 779-788.

15. Singh, S.V., Saunders, M.O., Moller, P.C., Haber, B., and Awasthi, Y.C. (1987): Comparative studies on the isozymes of glutathione S-transferase of rat brain and other tissues. Comp. Biochem. Physiol., 86B, 73-81.

16. Dierickx, P.J., and DeBeer, J.O. (1981): Two new anionic glutathione S-transferases from rat testes. Biochem. Int., 3, 565-571.

17. Eidne, K.A., and Kirsch, R.E. (1982): Identity of ligandin in rat testis and liver. Biochem. J., 203, 193-199.

18. Guthenberg, C., Astrad, I.M., Alin, P., and Mannervik, B. (1983): Glutathione transferases in rat testis. Acta Chem. Scand., 1337, 261-262.

19. Boyer, T.D., and Kenney, W.C. (1985): Acidic glutathione S-transferases of rat testis. Biochem. J., 230, 125-132.

20. Bass, N.M., Kirsch, R.E., Tuff, S.A., and Saunders, S.J. (1977): Radioimmunoassay of ligandin. Biochim. Biophys. Acta, 494, 131-132.

21. Campbell, J.A.H., Bass, N.M., and Kirsch, R.E. (1980): Immunohistological localization of ligandin in human tissues. Cancer, 45, 503-510.

22. Eidne, K.A., Bass, N.M., Sherman, M., Miller, R.P., and Kirsch, R.E. (1984): Ligandin concentrations in the steroidgenic tissues of rat during development. Biochim. Biophys. Acta, 801, 424-428.

23. Mannervik, B., and Guthenberg, C. (1981): Glutathione transferase (human placenta), in Methods in Enzymology, Vol. 77, ed. by Jakoby, W.B., Academic Press, New York, pp. 231-235. 
24. Djerassi, C., Engle, R.R., and Bowers, A. (1956): The direct conversion of steroidal $\Delta^{5}-3 \beta$-alcohols to $\Delta^{4}$ - and $\Delta^{4}$-3-ketones. J. Org. Chem., 21, 1547-1549.

25. Habig, W.H., Pabst, M.J., and Jakoby, W.B. (1974): Glutathione S-transferases. J. Biol. Chem., 249, 7130-7139.

26. Igarashi, T., Satoh, T., Ueno, K., and Kitagawa, H. (1983): Sex-related difference in the hepatic glutathione level and related enzyme activities in rat. J. Biochem., 93, 33-36.

27. Benson, A.M., and Talalay, P. (1976): Role of reduced glutathione in the $\Delta^{5}$-3-ketosteroid isomerase reaction of liver. Biochim. Biophys. Res. Commun., 69, 1073-1079.

28. Yoshimoto, T., Soberman, R.J., Lewis, R.A., and Austen, K.F. (1985): Isolation and characterization of leukotriene $\mathrm{C}_{4}$ synthase of rat basophilic leukemia cells. Proc. Natl. Acad. Sci. U.S.A., 82, 8399-8403.

29. Fukai, F., Kurano, M., Nishizawa, S., Kiire, Y., Nagai, T., and Katayama, T. (1988): Novel immunochemical characteristics of glutathione S-transferases of rat liver cytosol. Biochem. Int., 17, 945-951.

30. Sheehan, D., and Mantle, T.J. (1984): Evidence for two forms of ligandin in rat liver and kidney. Biochem. J., 218, 893-897.

31. Singh, S.V., Partridge, C.A., and Awasthi, Y.C. (1984): Rat lung glutathione S-transferases. Evidence for two distinct types of $22000 M_{\mathrm{r}}$ subunits. Biochem. J., 221, 609-615.

32. Talalay, P., and Benson, A.M. (1972): $\Delta^{5}-3$-Ketosteroid isomerase, in The Enzymes (3rd ed.), Vol. 6, ed. by Boyer, P.D. and Krebs, E.G., Academic Press, Florida, pp. 591-615.

33. Cheatum, S.G., and Warren, J.C. (1966): Purification and properties of $3 \beta$-hydrogenase and $\Delta^{5}$-3-ketosteroid isomerase from bovine corpora lutea. Biochim. Biophys. Acta, 122, 1-13.

34. Ford, H.C., and Engel, L.L. (1974): Purification and properties of the $\Delta^{5}-3 \beta$-hydroxysteroid dehydrogenase system of sheep adrenal cortical microsomes. J. Biol. Chem., 249, 1363-1368.

35. Ishii-Ohba, H., Inano, H., and Tamaki, B. (1986): Purification and properties of testicular $3 \beta$-hydroxy-5-ene-steroid dehydrogenase and 5-ene-4-en-isomerase. J. Steroid Biochem., 25 , 555-560.

36. Oleinick, N.J., and Koritz, S.B. (1966): The activation of the $\Delta^{5}$-3-ketosteroid isomerase in rat adrenal small particles by diphosphopyridine nucleotides. Biochemistry, 5, 715-724.

37. Fleischner, G., Robbins, J., and Arias, I.M. (1972): Immunological studies of Y protein. A major cytoplasmic organic anion-binding protein in rat liver. J. Clin. Invest., 51, 677-684. 